\title{
Composition and in vitro digestibility of leaves and stems of grasses and legumes harvested from permanent mountain meadows at different stages of maturity *
}

\author{
H. Ammar, S. López¹, O. Bochi-Brum, R. García and M.J. Ranilla
}

Department of Animal Production, University of León

E-24007 León, Spain

(Received 2 April 1999; accepted 7 October 1999)

\begin{abstract}
Chemical composition and in vitro digestibility were determined in stems and leaves hand-separated from grasses and legumes obtained from the first and subsequent cuts of a permanent meadow. Grasses from the first cut were classified in four groups according to their stage of maturity: vegetative, boot, head-bloom and seed stage. Crude protein $(\mathrm{CP})$ content was higher and neutral detergent fibre (NDF) content lower in legumes than in grasses, and in leaves than in stems. CP decreased and NDF increased with maturity in grasses. In general, legumes were more digestible than grasses. The digestibility of grasses harvested in the first cut decreased with increasing maturity. Leaves were more digestible than stems in legumes and grasses, although the relative difference between botanical parts was much larger in grasses than in legumes. The differences in digestibility between leaves and stems became more pronounced with increasing maturity, especially in terms of cell wall digestibility. As for forage quality, early cutting of permanent meadows would be recommended, so that grasses are harvested béfore they reach an advanced stage of maturity.
\end{abstract}

KEY WORDS: permanent mountain meadows, grasses, legumes, leaves, stems, nutritive value, stage of maturity

- Financial support received from Junta de Castilla y León (Project CSI3/99) and from Comisión Interministerial de Ciencia y Tecnología of Spain (Project AGF98-0188) is gratefully acknowledged

1 Corresponding author: Departmento de Producción Animal. Universidad de León. E-24071 León, Spain 


\section{INTRODUCTION}

Given the cold, dry conditions and agricultural practices prevalent in the highlands of northern Spain, it is difficult to apply the practices usually advised for permanent lowland pastures (Roumet et al., 1996). Permanent mountain meadows are characterized by a high diversity of species, and by a slower rate of grass growth. Herbage in permanent mountain meadows is usually harvested in late June (first cut) and again in early September (after summer regrowth), when weather conditions are most favourable for hay-making, the most traditional method of forage conservation in these areas of Spain (López et al., 1991a). The quality of the herbage harvested in September is better than that from the first cut, mainly because plants are cut at an earlier stage of maturity. The quality of the herbage obtained in June may vary depending on the cutting date.

Herbage yield is greatly influenced by the environmental conditions under which plants grow (Van Soest, 1994) and by management, especially cutting date and frequency (Pelaéz et al., 1995). Manipulating the date of the first cut may affect the distribution of yield and digestibility in the first and subsequent cuts.

Factors determining the nutritive value of herbage have, however, been less extensively investigated on permanent mountain meadows than on established swards. In particular, changes in chemical composition and digestibility of the different plant components with plant maturity are virtually unstudied. Thus, the objective of the present study was to assess the effects of maturity stage on chemical composition and in vitro digestibility of different botanical fractions of grasses and legumes commonly found in permanent mountain meadows in León (north-western Spain).

\section{MATERIAL AND METHODS}

\section{Sampling, botanical separation and sample preparations}

Samples were obtained from an irrigated permanent mountain meadow located in north-western Spain (León) at 1,100 m altitude. Samples were taken in 1996 from each of the three cuts of the meadow, carried out on May 31 (first cut), July 29 (regrowth of 59 days) and October 18 (regrowth of 81 days). An additional sample was obtained from a small plot within the meadow on June 28 , in order to obtain samples of grasses in a mature stage (similar to that normally found when the first harvest in June is delayed under practical conditions). All plots were cut with a mower-machine.

All the samples were immediately taken to the laboratory, and kept there in a refrigerator at $4^{\circ} \mathrm{C}$. Herbage samples were separated within the next two days into grasses, legumes, and ,weeds”. Predominant grasses were Dactylis glomerata, Hol- 
cus lanatus, and Lolium perenne, whereas Trifolium repens (white or ladino clover) and Trifolium pratense (red clover) were the only legumes found in the sward (López et al., 1991b). In both regrowths (second and third cuts) the amounts of red clover in the samples were not enough to determine its chemical composition or in vitro digestibility.

Grasses of the first cut showed large differences in their stage of maturity, thus a second botanical separation appeared to be necessary. Based on the stage of maturity, grasses were separated into three groups (G1, G2, and G3) according to the criteria established by Van Soest (1994). Moreover, from the herbage sample harvested on June 28, a sample of grasses in a mature stage (group G4) was obtained. The characteristics defining the stage of maturity of the four groups of grasses are described in Table 1. Grasses obtained in the second and third cuts showed a uniform stage of maturity, similar to that of G1. Samples of G2, G3 and G4 grasses were divided in two subsamples. One of them was considered representative of whole plants, the remaining subsample was separated into leaves (including leaf blades and sheaths), stems, and (if present in sufficient quantity) ears (heads). Only the sample representing the whole plants could be obtained for grasses of the G1 maturity group in all the three cuts, as the proportions of stems in these plants was negligible.

Legumes were at a similar stage of maturity in all of the three cuts, which would be the mid bloom or flowering stage as defined by Van Soest (1994). Samples of white and red clover (only from the first cut) were divided into two subsamples. The first (about one third of the total) was considered as representative of whole plants. The remaining subsample was used to obtain samples of leaves and stems (petioles) of each species in each cut. Since many of the red clover plants were in the flowering stage, for these species an additional sample of blooms was obtained.

TABLE 1

Classification of grasses harvested from permanent mountain meadows: groups G1, G2, G3 and G4 according to the stage of maturity of the plants (based on Van Soest, 1994)

\begin{tabular}{lll}
\hline Group & Stage of maturity & Description of the stage of maturity \\
\hline G1 & Vegetative or immature stage & $\begin{array}{l}\text { Plants reach } 1 / 3-2 / 3 \text { of its growth before blooming. } \\
\text { No visible buds, flowers or seedpods }\end{array}$ \\
G2 & Early head (boot) & $\begin{array}{l}\text { Complete stem elongation. Beginning of head } \\
\text { emergence (boot to carly head) }\end{array}$ \\
G3 & Head-bloom & $\begin{array}{l}\text { Appearance of buds. Ear is well formed in all plants, } \\
\text { with inflorescence in early anthesis }\end{array}$ \\
G4 & Seed & $\begin{array}{l}\text { Inflorescence in complete anthesis. Stage in which } \\
\text { seeds are well formed }\end{array}$ \\
\hline
\end{tabular}


All fresh samples were dried in a force-draft oven at $55^{\circ} \mathrm{C}$ for $72 \mathrm{~h}$, and then ground $(1 \mathrm{~mm})$ with a laboratory mill for chemical analysis and in vitro digestibility.

\section{Chemical analysis}

Nitrogen $(\mathrm{N})$ was determined by the Kjeldahl method (AOAC, 1995). Organic matter was calculated as the weight loss when samples were ashed at $550^{\circ} \mathrm{C}$ (AOAC, 1995). Neutral detergent fibre (NDF), acid detergent fibre (ADF), and acid detergent lignin (ADL) were determined by the procedures of Goering and Van Soest (1970), using the technique proposed by ANKOM (1998). In this procedure, extraction with detergents or reagents as well as washing take place on the sample $(500 \mathrm{mg})$ that is closed in a polyester, porous bag (size $5 \mathrm{~cm} \times 5 \mathrm{~cm}$; pore size $30 \mu \mathrm{m}$ ).

\section{In vitro digestibility}

In vitro digestibility was determined according to the Goering and Van Soest (1970) method with the modifications incorporated in the ANKOM technique (Bochi et al., 1997; ANKOM, 1998). In this procedure, the samples are weighed out ( $250 \mathrm{mg}$ ) into polyester bags (as above), which are then sealed with a heater. Then bags are placed in an incubation jar ( 25 bags in each jar), a 5 - $\mathrm{L}$ glass receptacle with a plastic lid provided with a one-way valve that prevents the accumulation of fermentation gases.

Rumen fluid was withdrawn from adult sheep fed with $1 \mathrm{~kg} / \mathrm{d}$ of a good quality hay. Rumen fluid of the different animals was mixed in a thermos flask and taken immediately to the laboratory, where it was strained through four layers of cheesecloth and kept at $39^{\circ} \mathrm{C}$ under $\mathrm{CO}_{2}$. The culture medium was that described by Goering and Van Soest (1970), and was kept at $39^{\circ} \mathrm{C}$ and saturated with $\mathrm{CO}_{2}$. Rumen fluid was diluted into the medium at a proportion of $1: 4(\mathrm{v} / \mathrm{v})$, and then 21 of buffered rumen fluid were anaerobically transferred to each incubation jar. Four jars were placed in an incubator (DAISY II, ANKOM) at $39^{\circ} \mathrm{C}$, with continuous rotation to facilitate the effective immersion of the bags in the rumen fluid.

After $48 \mathrm{~h}$ of incubation in buffered rumen fluid, bags were gently rinsed under cold tap water, and then rinsed again in a washing machine (short washing cycle 10 min-, with cold water). Bags were dried at $55^{\circ} \mathrm{C}$ for $48 \mathrm{~h}$, and in vitro rumen dry matter (DM) degradability (IVRdg, $\mathrm{g} / \mathrm{g}$ incubated) was calculated as the proportion of DM lost after $48 \mathrm{~h}$ incubation in rumen fluid [IVRdg $=(\mathrm{DM}$ incubated residual DM $48 \mathrm{~h}$ / $/ \mathrm{DM}$ incubated]. Incubation residues were then treated with a neutral detergent solution at $100^{\circ} \mathrm{C}$ for $1 \mathrm{~h}$ (ANKOM, 1998), to calculate the in vitro DM true digestibility (IVDMD), as proposed by Goering and Van Soest (1970):

$\operatorname{IVDMD}(\mathrm{g} / \mathrm{g}$ incubated $)=(\mathrm{DM}$ incubated - residual NDF $48 \mathrm{~h}) /$ DM incubated In vitro cell wall digestibility (IVCWD) was also calculated as

IVCWD $(\mathrm{g} / \mathrm{g}$ incubated $)=(\mathrm{NDF}$ incubated - residual NDF $48 \mathrm{~h}) / \mathrm{NDF}$ incubated. 


\section{RESULTS}

Chemical composition of different botanical fractions of grasses cut at different stages of maturity in the three harvest seasons is given in Table 2. The most notable change due to advancing maturity was found in the CP and ADL contents. $\mathrm{CP}$ content decreased and NDF, ADF and lignin contents increased with increasing maturity. Maturation effects were more pronounced in stems and whole plants than in leaves. Ears showed high CP contents, similar to those for leaves. NDF content in ears was intermediate between leaves and stems. Cell walls of ears seemed to be highly lignified. NDF, ADF and ADL contents of grasses of the second and third cuttings were similar to that for grasses at immature vegetative stage (G1).

The changes in chemical composition of grasses as maturity progressed were reflected in changes in in vitro DM and NDF digestibility (Table 3). Leaves were more digestible than stems. The digestibility of subsequent cuttings was similar to

TABLE 2

Chemical composition ( $\mathrm{g} / \mathrm{kg}$ dry matter) of whole plants and separated botanical fractions of grasses harvested from permanent mountain meadows at different stages of maturity

\begin{tabular}{lccccc}
\hline & $\begin{array}{c}\text { Organic } \\
\text { matter }\end{array}$ & $\begin{array}{c}\text { Crude } \\
\text { protein }\end{array}$ & $\begin{array}{c}\text { Neutral } \\
\text { detergent } \\
\text { fibre }\end{array}$ & $\begin{array}{c}\text { Acid } \\
\text { detergent } \\
\text { fibre }\end{array}$ & $\begin{array}{c}\text { Acid } \\
\text { detergent } \\
\text { lignin }\end{array}$ \\
\hline Whole plant & & & & \\
$\quad$ Cut 1-G1 & 915 & 161 & 595 & 283 & 18 \\
Cut 1-G2 & 934 & 120 & 639 & 326 & 25 \\
Cut 1-G3 & 942 & 90 & 650 & 346 & 33 \\
Cut 1-G4 & 949 & 65 & 672 & 373 & 50 \\
Cut 2 (59-d regrowth) & 925 & 121 & 609 & 289 & 19 \\
Cut 3 (81-d regrowth) & 921 & 122 & 568 & 257 & 16 \\
Leaves & & & & & \\
Cut 1-G2 & 919 & 168 & 619 & 303 & 18 \\
Cut 1-G3 & 922 & 114 & 624 & 309 & 23 \\
Cut 1-G4 & 921 & 83 & 620 & 342 & 27 \\
Stems & & & & & 28 \\
Cut 1-G2 & 942 & 63 & 668 & 369 & 38 \\
Cut 1-G3 & 953 & 48 & 676 & 366 & 56 \\
Cut 1-G4 & 951 & 28 & 689 & 383 & 39 \\
Ears (heads) & & & & & 44 \\
Cut 1-G2 & 943 & 166 & 637 & 302 & 58 \\
Cut 1- G3 & 951 & 152 & 608 & 287 & 325 \\
Cut 1-G4 & 948 & 127 & 644 & & \\
\hline
\end{tabular}

$\mathrm{Gl}=$ vegetative stage: $\mathrm{G} 2=$ boot stage; $\mathrm{G} 3=$ head stage; $\mathrm{G} 4=$ seed stage 
that of G1 grasses. In vitro digestibility decreased with increasing maturity. The greatest decline was observed between grasses G3 and G4. Changes with maturity were more pronounced in the stems than in the leaves.

Legumes had a higher CP content and lower NDF and ADF concentrations than grasses (Table 4). In most cases, the ADL content was greater in clover than in grasses, with the exception of G4 grasses. The chemical composition of white clover was similar in all three cuttings. Leaves had higher CP and lower NDF, $\mathrm{ADF}$ and lignin contents than stems, although the differences between botanical fractions were smaller than those observed for grasses. Red clover had lower CP and higher fibre contents than white clover in the first cutting, and the relative differences in chemical composition between leaves and stems were much larger for red clover than found among white clover components.

White clover had higher in vitro DM digestibility (IVRdg and IVDMD) coefficients than grasses (Table 5). Leaves were also more digestible than stems, although the relative difference between morphological parts was not as large as that observed among grass components.

TABLE 3

In vitro digestibility coefficients $(\mathrm{g} / \mathrm{g})$ of whole plants and separated botanical fractions of grasses harvested from permanent mountain meadows at different stages of maturity

\begin{tabular}{lccc}
\hline & $\begin{array}{c}\text { In vitro rumen } \\
\text { dry matter } \\
\text { degradability }\end{array}$ & $\begin{array}{c}\text { In vitro dry matter } \\
\text { truc digestibility }\end{array}$ & $\begin{array}{c}\text { In vitro cell wall } \\
\text { digestibility }\end{array}$ \\
\hline Whole plant & & & \\
Cut 1-G1 & 0.76 & 0.86 & 0.76 \\
Cut 1-G2 & 0.72 & 0.80 & 0.68 \\
Cut 1-G3 & 0.68 & 0.78 & 0.66 \\
Cut 1-G4 & 0.56 & 0.61 & 0.42 \\
Cut 2 59-d regrowth) & 0.77 & 0.86 & 0.77 \\
Cut 3 (81-d regrowth) & 0.79 & 0.86 & 0.75 \\
Leaves & & & \\
Cut 1-G2 & 0.78 & 0.85 & 0.75 \\
Cut 1-G3 & 0.76 & 0.84 & 0.74 \\
Cut 1-G4 & 0.67 & 0.74 & 0.58 \\
Stems & & 0.73 & 0.60 \\
Cut 1-G2 & 0.66 & 0.69 & 0.54 \\
Cut 1-G3 & 0.64 & 0.54 & 0.33 \\
Cut 1-G4 & 0.49 & & \\
Ears (heads) & & 0.80 & 0.69 \\
Cut 1-G2 & 0.70 & 0.78 & 0.64 \\
Cut 1-G3 & 0.68 & 0.61 & 0.40 \\
Cut 1-G4 & 0.55 & & \\
\hline
\end{tabular}

$\mathrm{G} 1=$ vegetative stage $; \mathrm{G} 2=$ boot stage; $\mathrm{G} 3=$ head stage: $\mathrm{G} 4=$ secd stage 
TABLE 4

Chemical composition $(\mathrm{g} / \mathrm{kg}$ dry matter) of whole plants and separated botanical fractions of legumes harvested from permanent mountain meadows

\begin{tabular}{|c|c|c|c|c|c|}
\hline & $\begin{array}{l}\text { Organic } \\
\text { matter }\end{array}$ & $\begin{array}{l}\text { Crude } \\
\text { protein }\end{array}$ & $\begin{array}{c}\text { Neuitral } \\
\text { detergent } \\
\text { fibre }\end{array}$ & $\begin{array}{c}\text { Acid } \\
\text { detergent } \\
\text { fibre }\end{array}$ & $\begin{array}{c}\text { Acid } \\
\text { detergent } \\
\text { lignin }\end{array}$ \\
\hline \multicolumn{6}{|c|}{ White or ladino clover } \\
\hline \multicolumn{6}{|c|}{ Cut 1} \\
\hline whole plant & 908 & 209 & 342 & 183 & 34 \\
\hline leaves & 915 & 310 & 323 & 125 & 19 \\
\hline stems & 903 & 154 & 354 & 204 & 36 \\
\hline \multicolumn{6}{|c|}{ Cut 2 (59-d regrowth) } \\
\hline whole plant & 909 & 183 & 376 & 216 & 44 \\
\hline leaves & 918 & 254 & 366 & 186 & 28 \\
\hline stems & 914 & 130 & 399 & 237 & 45 \\
\hline \multicolumn{6}{|c|}{ Cut 3 (81-d regrowth) } \\
\hline whole plant & 912 & 201 & 374 & 203 & 37 \\
\hline leaves & 916 & 272 & 343 & 159 & 29 \\
\hline stems & 913 & 134 & 393 & 230 & 40 \\
\hline \multicolumn{6}{|l|}{ Red clover } \\
\hline \multicolumn{6}{|l|}{ Cut 1} \\
\hline whole plant & 909 & 160 & 438 & 243 & 46 \\
\hline leaves & 913 & 268 & 347 & 113 & 21 \\
\hline stems & 905 & 101 & 474 & 310 & 51 \\
\hline blooms & 917 & 200 & 433 & 240 & 89 \\
\hline
\end{tabular}

\section{DISCUSSION}

Grasses and legumes show different development rates in each growing season. The environmental conditions in spring promote faster growth of grasses, so that they are in a better position to compete with legumes. Late cuts of the primary growth are therefore characterized by high proportions of grasses, usually more than $90 \%$ as reported by López et al. (1991b) that are in a mature stage. When this first cutting is delayed to July, some grasses are entering senescence. Therefore, the maturity of grasses in the first cut seems to be a critical factor affecting the nutritive value of the forages harvested from permanent mountain meadows.

Aftermath of the sward may be harvested in mid summer or early autumn. Plants harvested in subsequent cuts have higher protein and lower fibre contents, and higher digestibility than those harvested in the first cut (López et al., 1991a). The high environmental temperatures in the summer favour the growth of legumes, while grasses grow at slower rates. When the sward is mown, the harvested 
TABLE 5

In vitro digestibility coefficients $(\mathrm{g} / \mathrm{g}$ ) of legumes harvested from permanent meadows and of separated botanical fractions

\begin{tabular}{lccc}
\hline & $\begin{array}{c}\text { In vitro rumen } \\
\text { dry matter } \\
\text { degradability }\end{array}$ & $\begin{array}{c}\text { In vitro dry matter } \\
\text { true digestibility }\end{array}$ & $\begin{array}{c}\text { In vitro cell wall } \\
\text { digestibility }\end{array}$ \\
\hline $\begin{array}{l}\text { White or ladino clover } \\
\text { Cut 1 }\end{array}$ & & & \\
$\quad$ whole plant & 0.82 & 0.93 & 0.78 \\
$\quad$ leaves & 0.83 & 0.94 & 0.82 \\
stems & 0.82 & 0.91 & 0.74 \\
Cut 2 (59-d regrowth) & & & 0.70 \\
$\quad$ whole plant & 0.76 & 0.89 & 0.78 \\
leaves & 0.79 & 0.92 & 0.70 \\
$\quad$ stems & 0.75 & 0.88 & 0.76 \\
Cut 3 (81-d regrowth) & & & 0.78 \\
$\quad$ whole plant & 0.77 & 0.91 & 0.76 \\
leaves & 0.81 & 0.92 & \\
stems & 0.76 & 0.90 & 0.53 \\
Red clover & & & 0.69 \\
Cut 1 & & & 0.50 \\
whole plant & 0.67 & 0.79 & 0.70 \\
leaves & 0.66 & 0.76 & \\
stems & 0.65 & 0.78 & \\
blooms & & & \\
\hline
\end{tabular}

herbage shows a high legume to grass ratio, and all the plants are at an early vegetative stage of maturity. Therefore, herbage harvested after the summer regrowth gives a good quality hay, with a significantly better nutritive value than that obtained from the first cut (López et al., 1991a). Although plant age differed in the second and third cuttings of the meadow (59- and 81-day regrowths, respectively), there were small differences between both harvests in the chemical composition and in vitro digestibility of grasses and legumes. The weather conditions for each regrowth cycle vary relative to the date of the previous cutting, and higher temperatures in July-August promote lignification and more rapid physiological development of the plants, so that second cutting plants have a similar cell wall content at a younger age (Van Soest, 1994).

Botanical composition has a significant effect on forage quality given the differences between grasses and legumes in ruminal digestion. Legumes have generally faster rates of cell wall digestion and also greater potentially undegradable fractions than grasses, due to their higher lignin contents (López et al., 
$1991 \mathrm{~b}$; Jung and Deetz, 1993). When grasses and legumes are at a similar stage of maturity (as in the September regrowth) their ruminal degradability is similar, or that of the less lignified grasses is slightly higher (López et al., 1991b). However, in a late first cut grasses are at a much more advanced stage of maturity, and therefore their ruminal degradability is lower than that of legumes (López et al., 1991b).

A second parameter affected by harvest season and cutting date is the leaf:stem ratio of the plants. Plant maturity gives rise to a decline in their nutritive value, associated with a decreased proportion of leaves to stems and increased proportions of lignified tissues in leaves and stems. In grasses at an early stage of maturity (vegetative stage) the proportion of stems is almost negligible, and leaves constitute the major part of the plant. Stem development is necessary to support plant weight, and their proportion increases as plants mature. The leaf:stem ratio often has been taken as an index of forage quality, mainly in plants with large differences between stems and leaves in cell wall content and digestibility. Leaves are more digestible than stems in both grasses and legumes. Grass stems decrease substantially in digestibility as they mature, whereas this decline is less pronounced in leaves (Duru et al., 1995), so that the differences in digestibility between leaves and stems are larger as the plants become more mature (Lentz and Buxton, 1992). This is in agreement with other authors (Mowat et al., 1969; Collins, 1988; Gilliland, 1997) who have observed that at very initial stages of development stems may be as digestible as leaves, but after stem elongation, stems are less digestible than leaves in grasses and legumes. Legume leaves maintain their quality over the maturation process, while grass leaves decline in quality, though not as rapidly as stems (Mowat et al., 1969; Akin and Robinson, 1982). Furthermore, stem quality varies significantly more among grass species than does leaf quality (Halliday, 1989).

Crude protein contents also decreased with maturity, both in leaves and stems (Norton, 1982; Collins, 1988). Decrease of plant nitrogen concentration can be attributed to the formation of low-nitrogen structural support material (Greenwood and Barnes, 1978). Decreased DM digestibility with maturity was associated with increased cell wall contents. However, not only the cell wall concentration but other chemical, structural and anatomical characteristics of the cell wall must play an important role in limiting its ruminal digestion, since in vitro cell wall digestibility was also significantly affected by stage of plant maturity. The extent of cell wall lignification has been accepted as one of the parameters most related to cell wall digestibility (Jung and Deetz, 1993) because lignin is indigestible and constrains the digestion of the cell wall polysaccharides.

On the other hand, the overall dry matter digestion of forages is highly dependent on structural factors such as the relative proportion of cell types present in the plant tissues and the existence of factors restricting microbial access to walls (Ches- 
son, 1993), so some attention has been paid to the determination of rumen degradability of different cell types and on the quantification of limitations imposed by restricted availability of wall surface to microbial digestion. There are significant differences between plant tissues in their rumen degradability, so that metabolic and reserve tissues (parenchyma, mesophyll) are more degradable than supporting tissues (sclerenchyma, vascular bundle sheaths) (Gordon et al., 1985; López et al., 1993). Degradability of each tissue is also affected by maturity (López et al., 1993), and differences between tissues are not consistent across plant parts, particularly across families, i.e. grasses and legumes (Wilson and Hatfield, 1997). Cell types encountered in leaves are involved in metabolic functions of photosynthesis, with a high concentration of enzymes, and with a cell wall in which the thin primary wall predominates over a not very developed secondary wall (Engels and Schuurmans, 1992). In grasses, the leaves may have an important structural function through the lignified mid-rib. Stems are characterized by the presence of supporting tissues in which a secondary-lignified wall becomes predominant as stems mature (Engels and Schuurmans, 1992). Factors limiting stem fibre degradation seem to be different in grasses and legumes. In legumes the proportion of xylem could be the major factor, as xylem cells appear indigestible because of their highly lignified secondary walls (Wilson and Hatfield, 1997). In contrast, although all cell types in grass stems contain highly lignified secondary walls, the compositional limitation to wall digestion seems to lie in the lignified, indigestible middle lamella-primary wall, which restricts wall accessibility to rumen microorganisms (Wilson and Hatfield, 1997). Therefore, in grasses the anatomical structure of cells and tissues may be as important as cell wall chemistry in determining the rate and extent of fibre digestion.

\section{CONCLUSIONS}

Our results indicate that increased attention should be focused on morphological parameters (specially leaf:stem ratio and changes in nutritional quality of each part with maturity) in order to understand the variation in nutritive value due to maturation. The proportion of grasses at the seed stage will increase with increasing delay in the first cut of permanent mountain meadows and, therefore, the forage harvested will be of lower digestibility. The main reason for such a decrease in digestibility will be the advanced stage of development of grass stems, with a little-digestible cell wall. Forages harvested in early cuts in spring will be more digestible, and may allow another two forage harvests depending on environmental conditions. Although the digestible DM yield can be consistently improved by performing three cuts, the extra costs involved and the impact on some variables such as the meadow botanical diversity, should be evaluated. 


\section{REFERENCES}

Akin D.E., Robinson E.L., 1982. Structure of leaves and stems of Arrowleaf and Crimson clovers as related to in vitro digestibility. Crop Sci. 22, 24-29

ANKOM, 1998. Procedures for fiber and in vitro analysis. Available in Internet at: http:/ www.ankom.com

AOAC, 1995. Official Methods of Analysis. 16th Edition. AOAC International. Arlington, USA

Bochi O., López S., González J.S., Ovejero F.J., 1997. Comparison between the ANKOM and the conventional procedures to determine the in vitro digestibility of forages (in Spanish). ITEA 18 (vol. Extra), 37-39

Chesson A., 1993. Mechanistic models of cell wall degradation. In: H.G. Jung, D.R. Buxton, R.D. Hatfield, J. Ralph (Editors). Forage Cell Wall Structure and Digestibility. ASA-CSSA-SSSA, Madison, pp. 347-376

Collins M., 1988. Composition and fibre digestion in morphological components of an alfalfa-timothy sward. Anim. Feed Sci. Tech. 19, 135-143

Duru M., Calviere I., Tirilly V., 1995. Evolution de la digestibilité in vitro du dactyle et de la fétuque élevéc au printemps. Fourrages 14!, 63-74

Engels F.M., Schuurmans J.L.L., 1992. Relationship between structural development of cell walls and degradation of tissues in maize stems. J. Sci. Food Agr. 59, 45-51

Gilliland T.J., 1997. Changes induced by defoliation in the yield and digestibility of leaves and stems of perennial ryegrass (Lolium perenne) during reproductive development. Eur. J. Agron. 6. $257-264$

Goering M.K., Van Soest P.J., 1970. Forage Fiber Analysis (Apparatus, Reagents, Procedures and some Applications). Agricultural Handbook No. 379, USDA. Washington, DC

Gordon A.H., Lomax J.A., Chesson A., 1985. Preparation and composition of mesophyll, epidermis and fibre cell walls from leaves of perennial ryegrass (Lolium perenne) and Italian ryegrass (Lolium multiflorum). J. Sci. Food Agr. 36, 509-519

Greenwood D.J., Barnes A., 1978. A theoretical model for the decline in the protein content in plants during growth. J. Agr. Sci. 91, 461-466

Halliday L.J., 1989. Rumen degradation of various grass species at different stages of growth. Proccedings of XVI International Grassland Congress, Nice (France), pp. 933-934

Jung H.G., Deetz D.A., 1993. Cell wall lignification and degradability. In: H.G. Jung, D.R. Buxton, R.D. Hatfield, J. Ralph (Editors). Forage Cell Wall Structure and Digestibility. ASA-CSSASSSA, Madison, pp. 315-346

Lentz E.M., Buxton D.R., 1992. Digestion kinetics of orchardgrass as influenced by leaf morphology, fineness of grind, and maturity group. Crop Sci. 32, 482-486

López S., Carro M.D., González J.S., Ovejero F.J., 1991a. The effect of method of forage conservation and harvest season on the rumen degradation of forages harvested from permanent mountain meadows. Anim. Prod. 53, 177-182

Lópe $~ S .$, Carro M.D., González J.S., Ovejero F.J., 199 lb. Rumen degradation of the main forage species harvested from permanent mountain meadows in North-western Spain. J. Agr. Sci. 117, 363-369

López S., Murison S.D., Travis A.J., Chesson A., 1993. Degradability of parenchyma and sclerenchyma cell walls isolated at different developmental stages from a newly extended maize internode. Acta Bot. Neer. 42, 165-174

Mowat D.N., Kwain M.L., Winch J.E., 1969. Lignification and in vitro cell wall digestibility of plant parts. Can. J. Plant Sci. 49, 499-504

Norton B.W., 1982. Differences between species in forage quality. In: J.B. Hacker (Editor). Nutritional Limits to Animal Production from Pastures. C.A.B., Farnham Royal, pp. 89-110 
Peláez R., López S., Mantecón A.R., López J., 1995. Herbage yield in irrigated meadows in relation to the cutting time and number of harvests (in Spanish). Actas XXXV Reunión Cientifica de la S.E.E.P. $277-280$

Roumet J.P., Fleury P., Jeannin B., 1996. Facteurs de variation et prévision de la production fourragère en zone de haute montagne. Fourrages $145,77-90$

Van Soest P.J., 1994. Nutritional Ecology of the Ruminant. Cornell University Press, Ithaca

Wilson J.R., Hatfield R.D., 1997. Structural and chemical changes of cell wall types during stem development: consequences for fibre degradation by rumen microflora. Aust. J. Agr. Res. 48, $165-180$

\section{STRESZCZENIE}

Skład i strawność in vitro liści i lodyg traw i roślin motylkowych zbieranych w różnych stadiach dojrzalości $z$ trwalych ląk górskich

Badano wpływ dojrzałości rośliny na wartość pokarmową różnych części botanicznych traw i roślin motylkowych zbieranych z trwałych łąk górskich.

Oznaczano skład chemiczny i strawność in vitro łodyg i liści (oddzielanych ręcznie) traw i roślin motylkowych pierwszego i późniejszych pokosów z trwałych łąk. Trawy z l-go pokosu podzielono na 4 grupy weđług stanu dojrzałości: stadium wegetatywne, pączkowanie, kłoszenie-kwitnienie i zawiązanie nasiona. Zawartość białka ogólnego (CP) była większa, a NDF mniejsza w roślinach motylkowych niż w trawach, oraz w liściach niż łodygach. Wraz z postępem wegetacji traw obniżała się zawartość CP, a zwiększala NDF. Strawność obniżała się wraz z postępującą dojrzałością traw zbieranych jako 1-szy pokos. Liście były lepiej trawione niż lodygi, tak traw jak i motylkowych, chociaż względne różnicc pomiçdzy częściami botanicznymi były znacznie większe w przypadku traw niż motylkowych. Różnice w strawności pomiędzy liśćmi i łodygami zwiększały się wraz z postępująca dojrzałością roślin, specjalnie strawności ścian komórkowych.

Mając na uwadze jakość pasz zielonych, powinno być zalecane wczesne koszenie trwałych łąk, tzn. traw przed osiągnięciem zaawansowanego stadium dojrzałości. 